\title{
Model for the environmental impact assessment of neighbourhoods
}

\author{
D. Trigaux, K. Allacker \& F. De Troyer \\ Department of Architecture, Faculty of Engineering, \\ University of Leuven, Belgium
}

\begin{abstract}
In order to move towards a sustainable built environment, modern cities need to be planned and organized differently, focussing not only on the characteristics of individual buildings but also on the relations between buildings and infrastructure works. Based on an existing Life Cycle Assessment (LCA) method for buildings, this paper proposes a model to assess the environmental impact of building clusters, together with the required road infrastructure. A hierarchic assessment structure, using the principles of the "element method for cost control" and a subdivision in different scale levels, is presented and methodological issues are discussed. To illustrate the methodology, abstract neighbourhood models are compared consisting of different dwelling types and the related amount of road infrastructure. The results revealed substantial environmental impact differences between the analysed alternatives, showing the importance of optimizing the layout and density of neighbourhoods.

Keywords: neighbourhood, road infrastructure, element method, Life Cycle Assessment.
\end{abstract}

\section{Introduction and objectives}

Considering the interactions between buildings and their surroundings (e.g. impact on local mobility and necessary infrastructure), the higher scale of the built environment has become an important focus in sustainable decision taking. In order to reduce the environmental footprint of the built environment, methods such as Life Cycle Assessment (LCA) can be used to assess the generated environmental impacts during the whole building life cycle. However, to date only few studies have focused on the LCA of neighbourhoods $[1,2]$. 
Different LCA studies have been carried out on individual buildings [3] or road infrastructure solely $[4,5]$ but without integration at the higher scale level.

The purpose of this paper is to elaborate a model to assess the environmental impact of building clusters, together with the required road infrastructure. To deal with complexity, a hierarchic assessment structure, using the principles of the "element method for cost control" [3] is presented. The methodology is illustrated based on a comparison of abstract neighbourhood typologies, consisting of 4 representative dwelling types and the related amount of road infrastructure. Based on this analysis the importance of spatial planning decisions related to the layout of neighbourhoods will be questioned.

In the subsequent section the methodological aspects are described, focussing on the environmental impact assessment and the "element method for cost control". In section 3 the methodology is implemented to assess the environmental impact of an asphalt road for local traffic and subsequently to analyse the different abstract neighbourhood models. Conclusions are drawn in the final section.

\section{Methodology}

\subsection{Environmental impact assessment}

The environmental impact assessment used in this paper is based on an LCA method developed within the MMG ("Milieugerelateerde Materiaalprestatie van Gebouwelementen") research project, commissioned by the Public Waste Agency of Flanders (OVAM) [6]. Within this project an evaluation method for the environmental performance of building elements is developed, specific for the Belgian context. In a recent project [7] this method was extended to evaluate buildings, based on a simplified calculation tool. This paper discusses the extension of this tool to integrate the impact of road infrastructure and simulate abstract neighbourhood typologies. In the following paragraphs the main methodological aspects of the MMG method are summarized.

Concerning the system boundaries the environmental impact assessment covers the whole building life cycle from cradle to grave (an average building life span of 60 years is considered). In accordance with the European CEN standards [8], the life cycle is subdivided in four stages: production, construction, use and end-of-life (EOL) stage (Figure 1). The production stage covers the extraction of raw materials, transport to the factory and manufacturing processes. The second stage (construction) includes the transport to the construction site and impacts of construction activities. Thirdly, the use stage considers the impacts from cleaning, maintenance, replacement of components and energy use in buildings. Finally, the EOL stage covers the demolition activities, waste processing and disposal, inclusive all transport steps. To assess the impact of these four life cycle stages, scenarios have been defined. A detailed description of the scenarios and assumptions can be found in the final report of the MMG project [6]. 


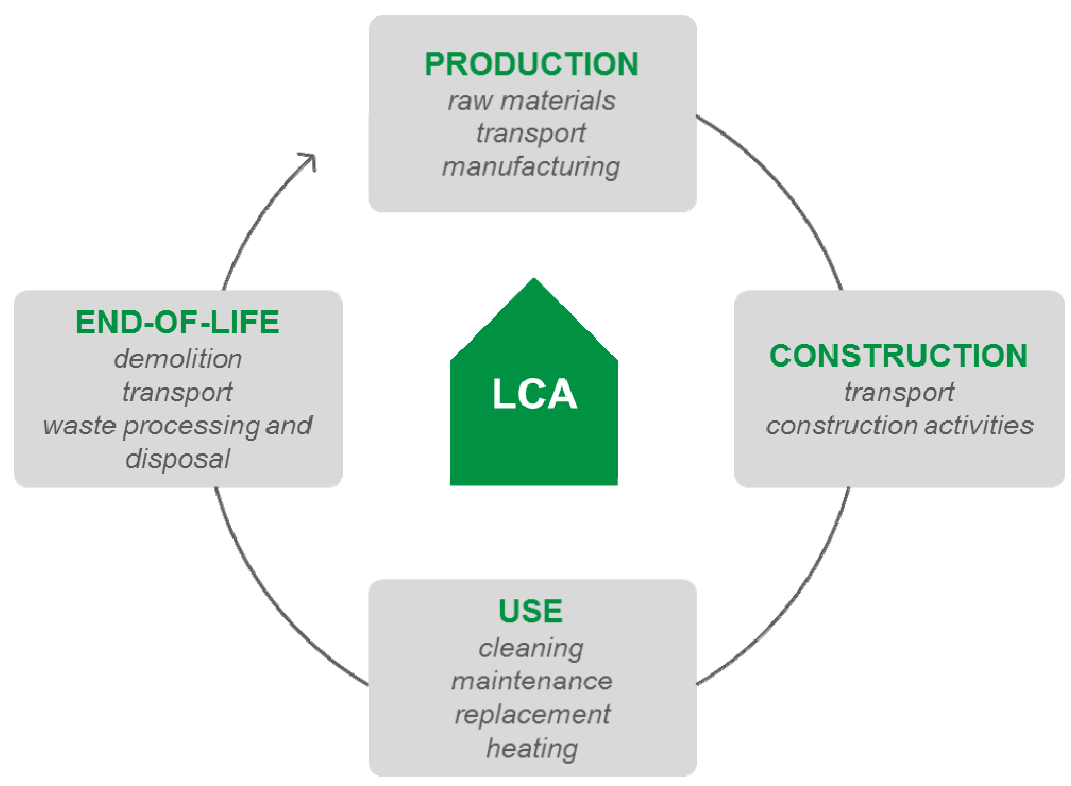

Figure 1: Life cycle assessment of buildings.

The MMG environmental impact assessment method allows assessing both a wide range of individual impact indicators and an aggregated single-score indicator. The latter is expressed in environmental costs (external costs caused by environmental impacts). The wide range of environmental impacts considered include the impact categories defined by the CEN TC350 standards $[8,9]$ (further referred to as CEN indicators):

- $\quad$ Global warming

- $\quad$ Depletion of the stratospheric ozone layer

- $\quad$ Acidification of land and water sources

- $\quad$ Eutrophication freshwater and marine

- $\quad$ Photochemical oxidant formation

- $\quad$ Abiotic depletion of non-fossil resources

In addition to the CEN impact categories, other impact categories are considered, based on the International Reference Life Cycle Data System (ILCD) Handbook [10] and consultation of Flemish-Belgian policy makers (further referred to as $\mathrm{CEN}+$ indicators):

- $\quad$ Human toxicity, cancer and non-cancer effects

- $\quad$ Particulate matter formation

- $\quad$ Ionising radiation, human health

- $\quad$ Ecotoxicity (terrestrial, freshwater and marine)

- $\quad$ Land use: land occupation (agricultural/forest and urban)

- $\quad$ Land use: land transformation (tropical rain forest)

For the life cycle inventory the Ecoinvent database (version 2.2) was used [11], giving priority to records representative for West-Europe. When no 
West-European data is available, records representative for Switzerland are used and adapted to the Belgian context (replacing the Swiss electricity mix and transport processes by European corresponding processes) [6].

\subsection{Element method for cost control}

Due to the complexity of neighbourhoods a well-structured evaluation is required to deal with the huge quantity of data. In the MMG method the assessment structure is based on the element method for cost control [3]. The basic principle is the hierarchical subdivision of the building in functional elements (e.g. walls, floors, technical installations) for which environmental data can easily be calculated. A distinction can be made between the following scale levels: building materials (e.g. brick, mortar, plaster), work sections (e.g. brickwork, plasterwork), building elements (e.g. internal wall including finishes) and buildings. This hierarchical structure allows using the results from the lower scale level for analysis at the higher scale levels. In this paper, this approach is extended to evaluate neighbourhoods, as a combination of buildings, networks (e.g. roads, utilities) and open spaces (Figure 2).

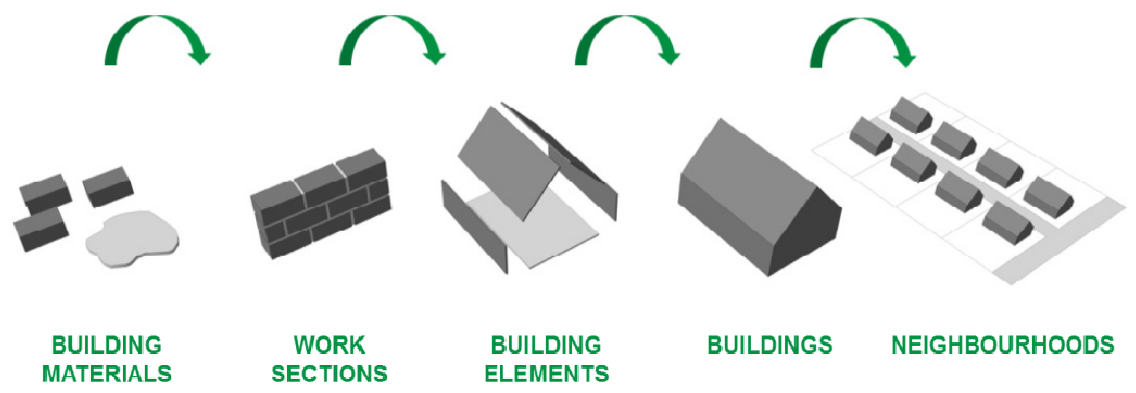

Figure 2: Element method for cost control and scale levels.

For the implementation of the element method in the MMG tool, the $\mathrm{BB} / \mathrm{SfB}$-plus classification system (Belgian version of the international $\mathrm{CI} / \mathrm{SfB}$ classification system) [12], is used. Elements are subdivided in nine main categories, according to their function (Table 1). The last category "External works" can be used to define all the works outside the buildings such as road infrastructure or utilities. An overview of the functional elements for this category is given in Figure 3. In order to integrate the impact of road infrastructure in the MMG tool, we only focussed on the functional element "(94) Ground surface treatments", including works related to roads, squares and green areas. In accordance with the BB-SfB plus principles, we made a proposal for a further subdivision of this functional element in sub-elements, covering the different road work sections (e.g. road base, road surfacing, road paint etc.), (Table 2). 
Table 1: Main element categories BB/SfB-plus [12].

\begin{tabular}{l|l} 
Code & Name element \\
\hline$(1-)$ & Ground, substructure \\
$(2-)$ & Structure \\
$(3-)$ & Secondary elements \\
$(4-)$ & Finishes \\
$(5-)$ & Services (mainly piped) \\
$(6-)$ & Services (mainly electrical) \\
$(7-)$ & Fittings \\
$(8-)$ & Loose furniture, equipment \\
$(9-)$ & External works
\end{tabular}

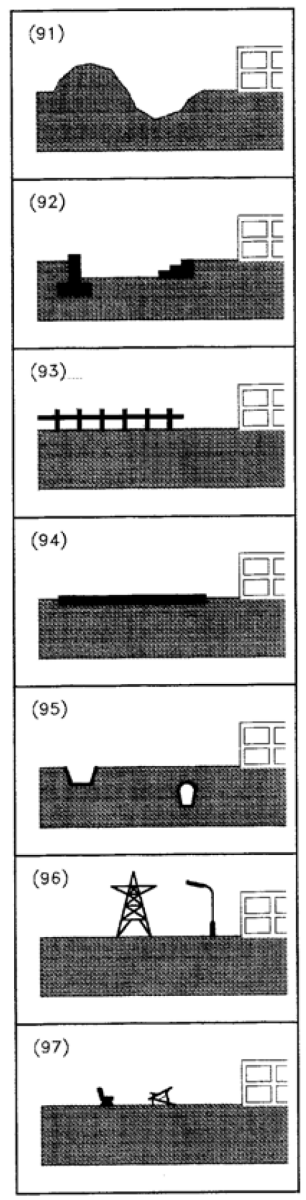

(91) GROUND PREPARATION

examples: ground clearing, shaping

(92) MINOR STRUCTURE

examples: shelters, sheds

(93) ENCLOSURES

examples: fences, gates

(94) GROUND SURFACE TREATMENTS

examples: roads, squares, green areas

(95) PIPED SERVICES

examples: drainage, district heating

(96) ELECTRICAL SERVICES

examples: outdoor lighting

(97) FITTINGS

examples: hoardings, outdoor benches

Figure 3: $\quad$ BB-SfB-plus classification for external works (9-) [12]. 
Table 2: $\quad$ Proposed subdivisions in sub-elements for the functional element “(94) Ground surface treatments".

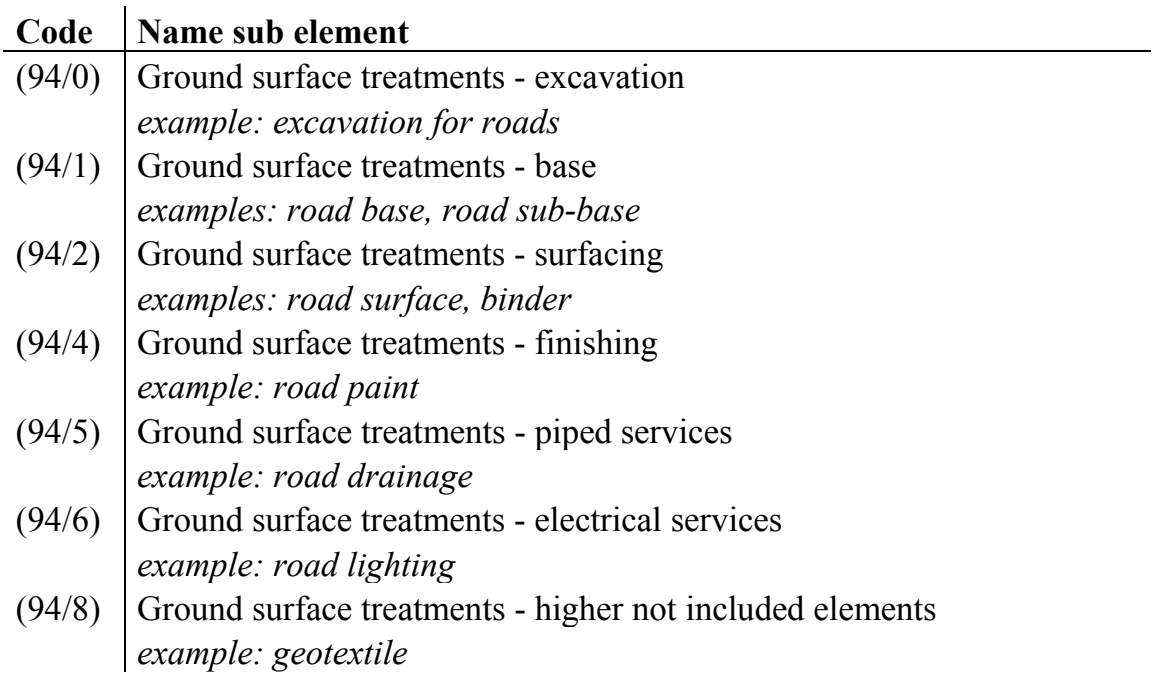

\section{Results case studies}

\subsection{Environmental profile of an asphalt road for local traffic}

The methodology is illustrated with the example of a representative Belgian road section, commonly used for local traffic. The analysed road is composed of a geotextile (for separation of subgrade and sub-base), sub-base, base and two asphalt layers (top layer and sub layer). Concerning the road base and sub-base, recycled materials (crushed rubble) are generally used in the Belgian context. The detailed composition of the analysed asphalt road and the related work sections are shown in Figure 4.

Regarding the use stage, it is not straightforward to define maintenance and replacement scenarios because those depend not only on the technical characteristics of the materials but also on external factors (e.g. amount of traffic, climatic conditions) and budgets available by municipalities. Based on publications from the road construction sector and LCA studies [5], [13], we defined the following maintenance and replacement frequencies:

- Major maintenance of asphalt top layer (replacement of 5\% of the top layer surface): 10 year

- $\quad$ Replacement of asphalt top layer and sub layer: 30 year

Using the extended MMG-tool, the environmental impact of the different work sections was calculated and combined to an environmental profile (expressed in environmental costs per meter road). The results for a 5 meters wide road with a life span of 60 years are shown in Figure 5. While the base and sub-base have a low environmental impact due to the use of recycled materials (crushed rubble), the asphalt layers are contributing most to the environmental 
profile (about $75 \%$ of the life cycle environmental impact). When looking at the life cycle processes (Figure 6), the production and replacement of sub-elements results in the highest environmental costs. This shows the importance of the choice of the replacement scenarios for the surfacing layers.

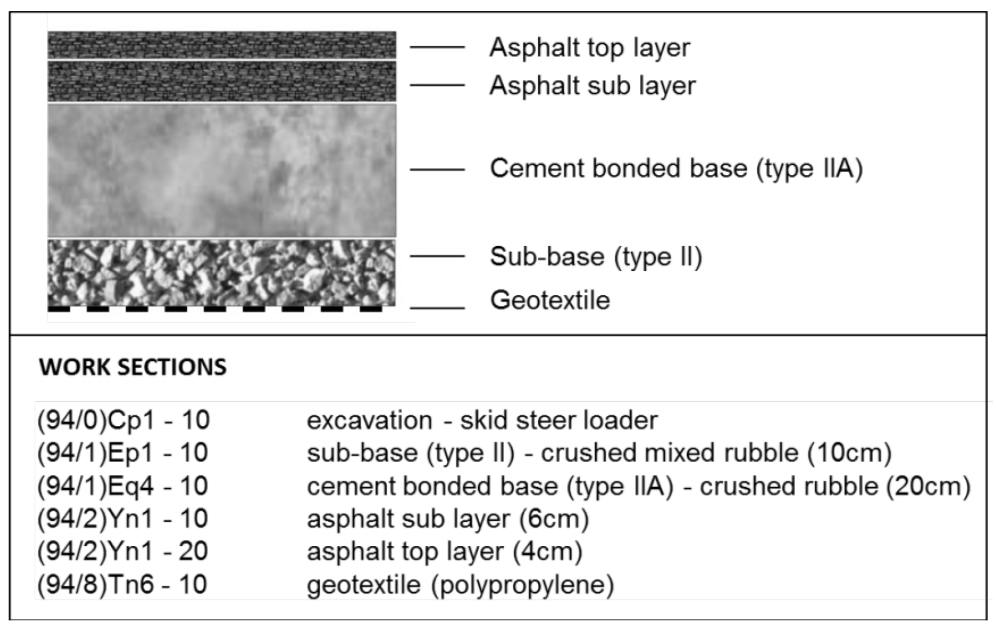

Figure 4: Composition of the analysed asphalt road and related work sections.

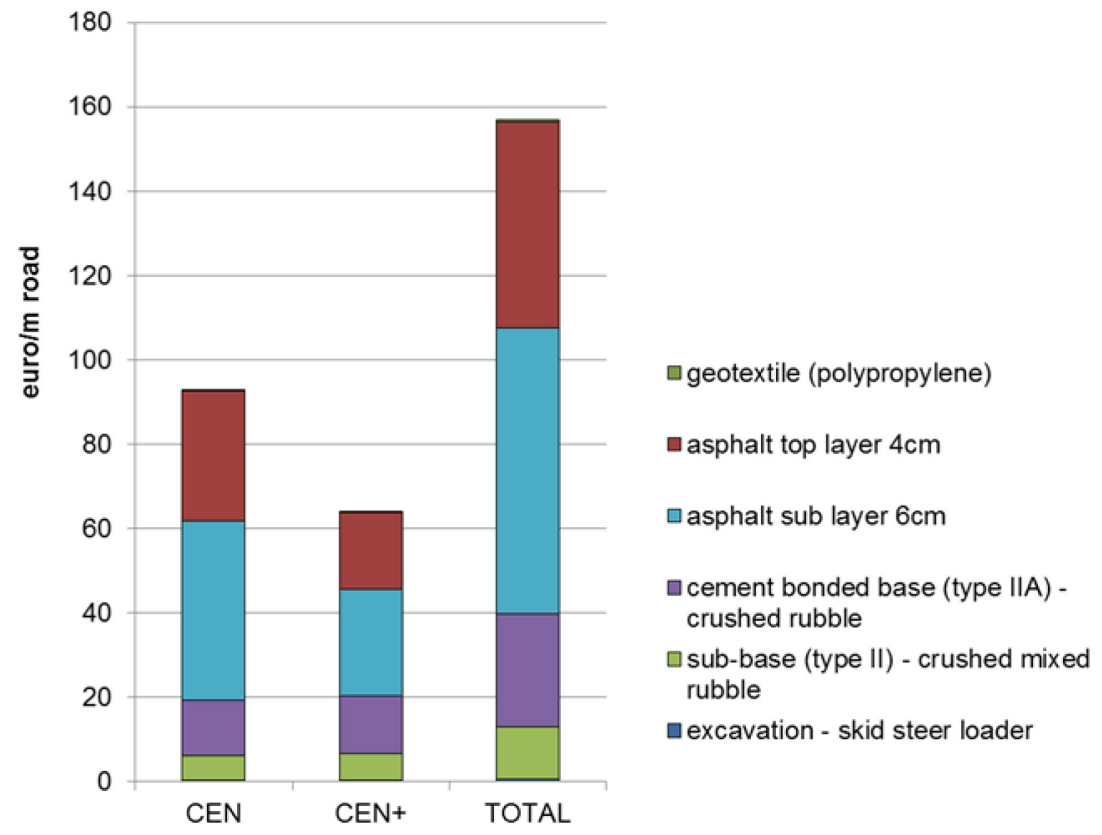

Figure 5: Life cycle environmental cost of the asphalt road, subdivided per work section. 


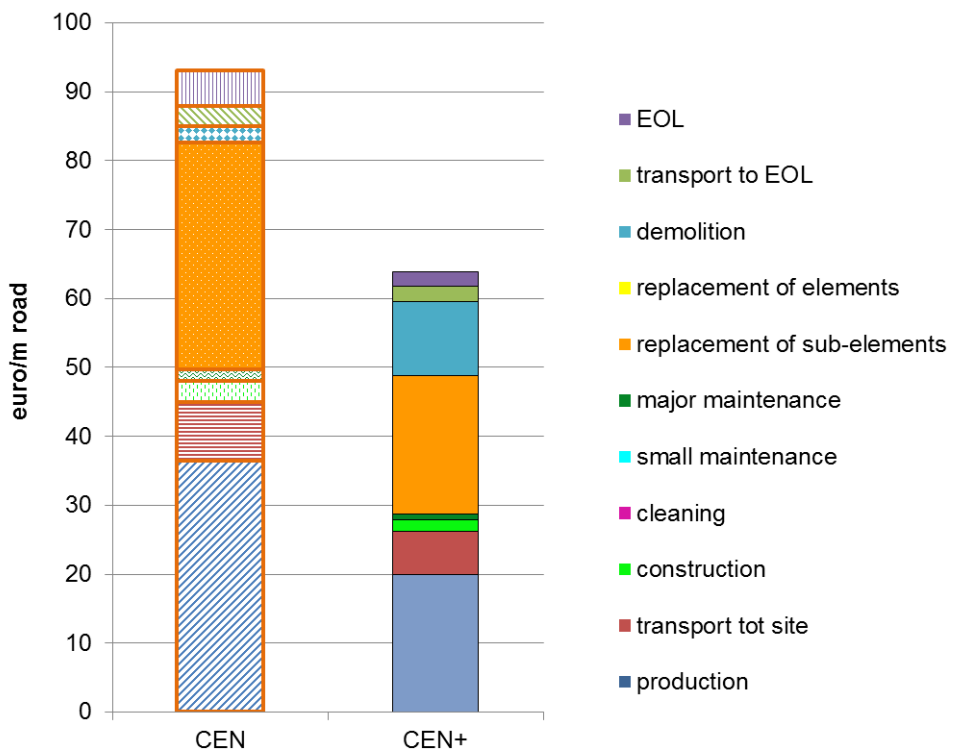

Figure 6: Life cycle environmental cost of the asphalt road, subdivided per life cycle phase (hatches $=$ CEN indicators; solid colors $=\mathrm{CEN}+$ indicators $)$.

\subsection{Analysis of abstract neighbourhood models}

For the evaluation at the neighbourhood level, four typologies are defined (Figure 7), based on a selection of representative dwelling types: detached houses (model 1), semi-detached houses (model 2), terraced houses (model 3) and apartments (model 4). Those dwelling types result in a different amount of road infrastructure per floor area. While the model of the detached houses generates a lot of infrastructure per $\mathrm{m}^{2}$ total floor area, this amount successively decreases in model 2, 3 and 4.

The simulations are carried out based on a set of standard building elements, selected from the database of the MMG project (Table 3) [6]. Only the space delimiting elements (floors, walls, roofs, stairs, windows and doors) are included in the assessment. Technical systems (e.g. heating, ventilation, water supply etc.) are not considered. The life cycle environmental costs (Figure 8) of the four alternative neighbourhoods differ significantly: the environmental impact of model 1 is about $50 \%$ higher compared to the more dense model 3 . The contribution of road infrastructure (from about 1\% of the total impact in model 4 to about $6 \%$ in model 1) is also smaller in the neighbourhood models with a higher density but seems relatively limited compared to the impact of the buildings. A more detailed picture of the processes contributing to the environmental impact (Figure 9) shows that the production phase and heating of buildings are contributing most. Those processes are directly linked to the 
dwelling typology (clustered dwellings often result in a lower amount of building elements and building skin per floor area (resulting in less heat loss per $\mathrm{m}^{2}$ of floor)). It has to be noticed that the apartment type has a relatively high environmental impact per $\mathrm{m}^{2}$ of floor (compared to the model with detached houses) due to the impact of collective spaces (e.g. stairs, technical rooms) which is distributed over the different dwellings.

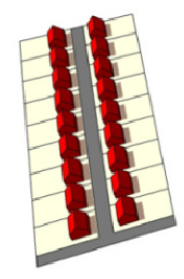

MODEL 1

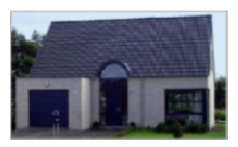

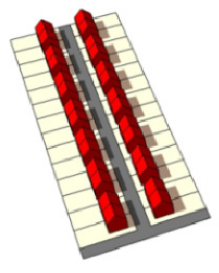

MODEL 2

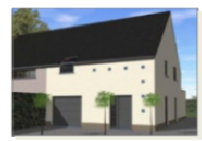

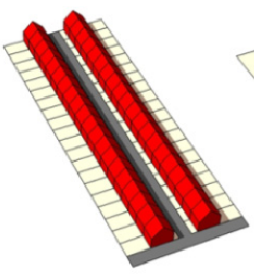

MODEL 3

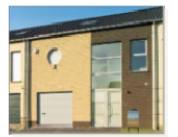

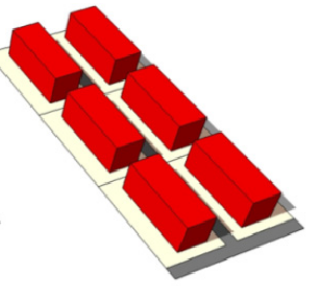

MODEL 4

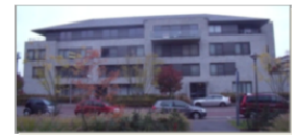

Figure 7: Neighbourhood models based on four representative dwelling types: detached houses (model 1), semi-detached houses (model 2), terraced houses (model 3) and apartments (model 4).

Table 3: Overview of the analysed building elements.

\begin{tabular}{|c|c|}
\hline Building element & Standard variant \\
\hline Floor on grade & $\begin{array}{l}\text { concrete slab - } 5 \mathrm{~cm} \text { PUR foam - screed mix - fired clay } \\
\text { tiles }\end{array}$ \\
\hline Outer wall & $\begin{array}{l}\text { facing brick - hollow brick clay }-6 \mathrm{~cm} \text { rockwool - } \\
\text { gypsum plaster - acrylic paint }\end{array}$ \\
\hline $\begin{array}{l}\text { Load bearing } \\
\text { inner wall }\end{array}$ & $\begin{array}{l}\text { acrylic paint - gypsum plaster - hollow brick } 14 \mathrm{~cm}- \\
\text { gypsum plaster - acrylic paint }\end{array}$ \\
\hline $\begin{array}{l}\text { Non-bearing } \\
\text { inner wall }\end{array}$ & $\begin{array}{l}\text { acrylic paint - plasterboard - metal stud }+10 \mathrm{~cm} \text { glass } \\
\text { wool }- \text { plasterboard - acrylic paint }\end{array}$ \\
\hline Floor & $\begin{array}{l}\text { acrylic paint - gypsum plaster - concrete slab } 15 \mathrm{~cm}- \\
\text { screed mix - fired earth tiles }\end{array}$ \\
\hline Staircase & wooden open staircase - varnish - wooden banister \\
\hline Flat roof & $\begin{array}{l}\text { EPDM - } 10 \mathrm{~cm} \text { PUR - concrete slope layer - concrete } \\
\text { slab } 15 \mathrm{~cm} \text { - gypsum plaster - acrylic paint }\end{array}$ \\
\hline Pitched roof & $\begin{array}{l}\text { Clay tiles - wood fibre board - purlins and jack rafters }+ \\
18 \mathrm{~cm} \text { rockwool - plasterboard - acrylic paint }\end{array}$ \\
\hline Window & PVC frame - standard double-glazed $\left(\mathrm{U}=1.1 \mathrm{~W} / \mathrm{m}^{2} \mathrm{~K}\right)$ \\
\hline Interior doors & MDF frame - plain door \\
\hline
\end{tabular}




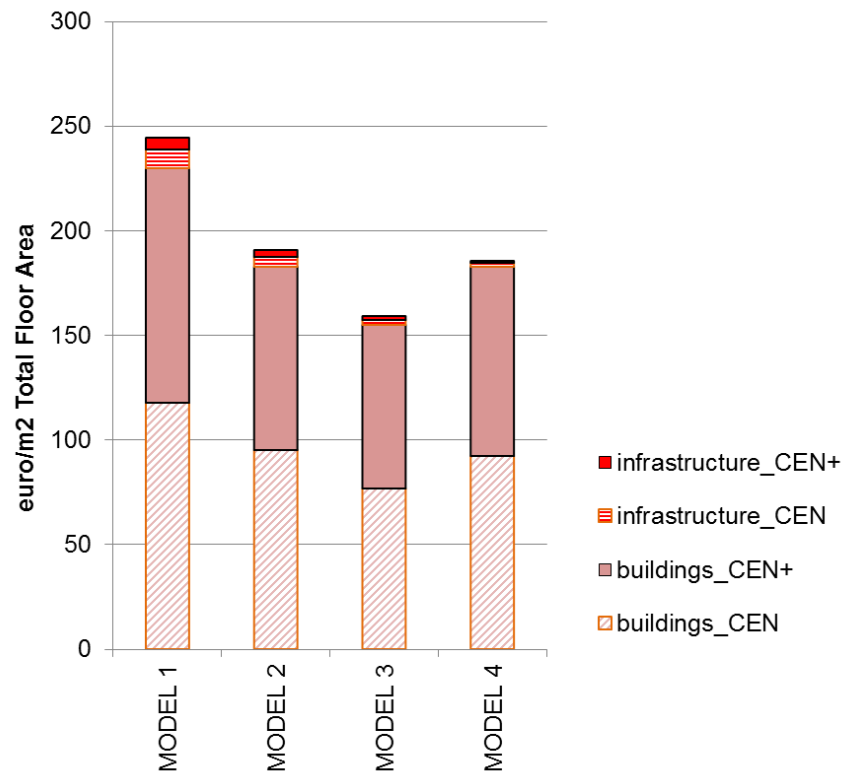

Figure 8: Life cycle environmental cost of the analysed neighbourhood models, showing the contribution of buildings and road.

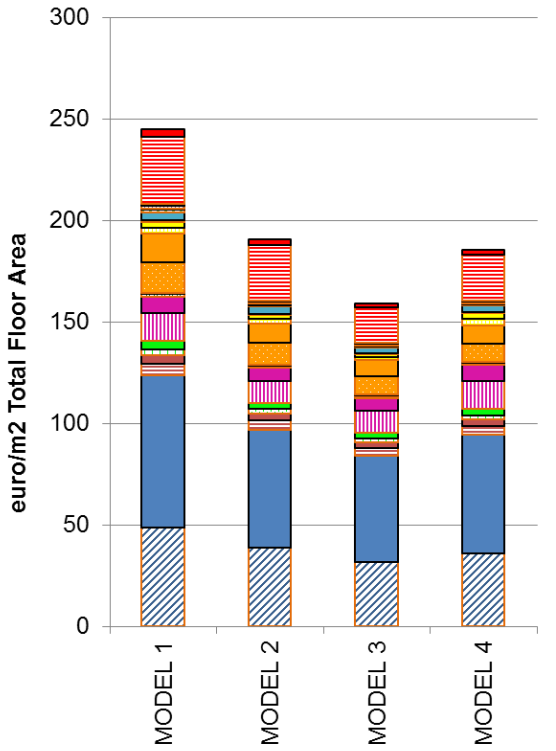

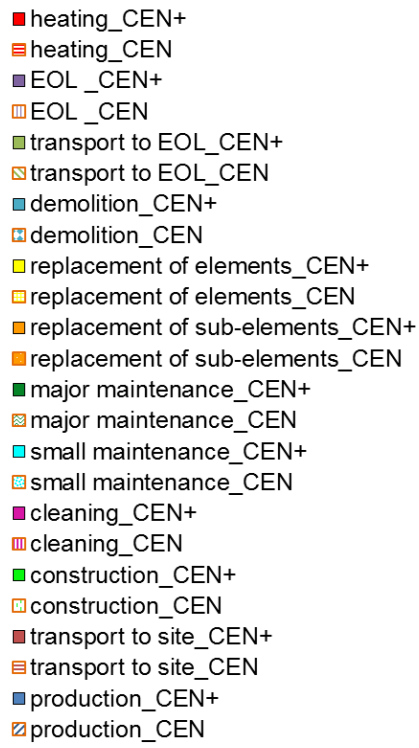

Figure 9: Life cycle environmental cost of the analysed neighbourhood models, subdivided per life cycle phase. 


\section{Conclusions and recommendations}

In this paper a model is elaborated to assess the environmental impact of building clusters, together with the required road infrastructure. The hierarchic assessment structure of the element method for cost control is extended to the neighbourhood scale, enabling an easy evaluation of neighbourhoods during the different stages of the design process (by changing the neighbourhood geometry and selected technical solutions).

The methodology is illustrated based on abstract neighbourhood models, consisting of different dwelling types. The simulation results highlight the importance of neighbourhood layouts and choices related to infrastructure and building typologies. The potential environmental cost reduction is much higher than when only focussing on the optimisation of a specific process such as operational energy. Similar results were found in studies at the building level pointing out the importance of the dwelling type and layout, above the insulation level and better performing heating systems [14].

Although the impact of neighbourhood infrastructure seems relatively limited, it is expected that this will increase when all infrastructural components such as bicycle paths and foot paths, electricity and water networks, sewerage and district heating are considered as well. It is furthermore recommended to make a more detailed analysis of the maintenance and replacement scenarios of the road surfacing layers which are contributing most to the environmental profile of roads.

Based on this limited study of neighbourhood typologies, it can be concluded that spatial planning decisions have a big influence on the environmental impact of neighbourhoods. The priority should be to design denser neighbourhood layouts in order to reduce the amount of infrastructure and optimize the material and energy use in buildings. In a second step, the environmental impact can be further reduced through more specific process optimisations (e.g. improving the building insulation level or using low impact building materials).

\section{References}

[1] Forsberg, A., Environmental Assessment of the Urban Environment Development and first application of the environmental load profile for Hammarby Sjöstad, Licentiate thesis, Royal Institute of Technology, Stockholm, 2003, http://www.diva-portal.org/smash/get/diva2:7550/ FULLTEXT01.pdf

[2] Herfray, G., Contribution à l'évaluation des impacts environnementaux des quartiers, PhD dissertation, Mines ParisTech, Paris, 2012, http://tel.archives-ouvertes.fr/docs/00/65/82/20/PDF/Herfray.pdf

[3] Allacker, K., Sustainable building, The development of an evaluation method, PhD dissertation, KU Leuven, Heverlee, 2010.

[4] Hoang, T., Durand, C., Ventura, A., Jullien, A. and Laurent, G., A global tool for environmental assessment of roads - Application to transport for 
road building, European Conference of Transport Research Institutes, Hague, 2005,

http://www.ectri.org/YRS05/Papiers/Session-3bis/ventura.pdf

[5] Gschösser, F., Environmental Assessment of Road Constructions, Life

Cycle Assessment of Swiss Road Pavements and an Accompanying Analysis of Construction and Maintenance Costs, PhD dissertation, ETH Zurich, Zurich, 2011, http://e-collection.library.ethz.ch/eserv/eth:5578/eth5578-02.pdf

[6] Allacker, K., Debacker, W., Delem, L., De Nocker, L., De Troyer, F., Janssen, A., Peeters, K., Servaes, R., Spirinckx, C. and Van Dessel, J., Environmental profile of building elements, OVAM, Mechelen, 2013, www.ovam.be/jahia/Jahia/pid/2594?lang=null

[7] Trigaux, D., De Troyer, F., Debacker, W., Delem, L., Janssen, A. and Van Dessel, J., Vertaling van de MMG-output naar beleidstoepassingen in het kader van specifieke gebruikersdoelgroepen (translated title: Translation of the MMG output to policy applications in function of specific user groups), OVAM, Mechelen, Final report, 2013, http://www.ovam.be/jahia/Jahia/cache/offonce/pid/176?actionReq=action PubDetail\&fileItem $=3238$

[8] CEN, Ed., EN 15978 Sustainability assessment of construction works assessment of environmental performance of buildings - calculation method, 2011.

[9] CEN, Ed., EN 15804 Sustainability of construction works Environmental product declaration - Core rules for the product category of construction products, 2012.

[10] Joint Research Centre (JRC) of European Commission - Institute for Environment and Sustainability (IES), International Reference Life Cycle Data System (ILCD) Handbook - General guide for Life Cycle Assessment - Detailed guidance, 2010.

[11] Ecoinvent, http://www.ecoinvent.ch/

[12] De Troyer, F., BB/SfB-plus. Een functionele hiërarchie voor gebouwelementen, Acco: Leuven, 2008.

[13] Benelux Bitume, Ed., Asfaltverhardingen, De juiste keus, Economische, milieu, maatschappelijke en technische overwegingen bij de keuze van verhardingssytemen (Translated title: Asphalt surfacing, The right choice, Economic, environmental, societal and technical considerations for the choice of surfacing systems). 2005, http://www.vbwasfalt.org/cms/Media/Publicaties\%20en\%20video/Rapport $\% 20$ Asfalt $\% 20 \mathrm{de} \% 20$ juiste $\% 20$ keuze\%202005.pdf

[14] Allacker, K. and De Troyer, F., Moving towards a more sustainable Belgian dwelling stock, The passive standard as the next step? Journal of Green Building, vol. 8, no. 2, pp. 112-132, Apr. 2013, http://www.journalofgreenbuilding.com/doi/abs/10.3992/jgb.8.2.112 